\title{
Jakarta, Mental Landscape, and Social Issues : Case Study of Rindu Kami Pada-Mu
}

\author{
Ekky Imanjaya \\ Film Department Bina Nusantara University \\ eimanjaya@binus.edu
}

\begin{abstract}
Although Jakarta seems to be the most favorable setting for Indonesian films, most Jakarta films are not about the city or its people, but rather about a large town with no name (Jufri (eds.) 1992: 23). Asrul Sani highlights the importance of showing physical pictures such as prominent buildings and adequate clothing, and a mental landscape. In Andre Bazin's term, the mental landscape shows the "spiritual vitality" of one city on-screen, which construes s specific indications referring to that particular city. Some social and gender issues within the films will be revealed and questioned by exploring the mental landscape. This paper will discuss Rindu Kami pada-Mu (Of Love and Eggs, Garin Nugroho, 2004). I try to answer the question: how does Rindu Kami represent post-Reform Jakarta and its social and gender issues? I argue that Rindu Kami pada-Mu represents the backdoors of Post-1998 Jakarta. Not only depicting the physical and mental landscape of lower-class society, such as a slum market, the film also portrays the psychological developments and achievements of urban people. They struggle against the remaining ideology of the New Order (State Ibuism, militarypolitical system) and its concrete implementations (domestic violence, demolitions) in social issues. By doing textual analysis, using theories of Mental Landscape and Stuart Hall's Representation, I will elaborate on "the other side of Jakarta" and its social issues, namely solidarity and communication Issues. Gender issues, such as the depiction of negative male characters and masculine militarism, will be discussed.
\end{abstract}

Keyword: Mental Landscape, Representation of Jakarta, Indonesian Film, Social Issues, Gender Issues

\section{Introduction:}

As a capital city, Jakarta has many stories, dynamics of people's progressions and interactions, and events of social and cultural exchanges. However, many of Jakarta's films do not represent Jakarta and its social and cultural issues. The movies do not have a mental landscape, a spiritual vitality that portrays the city and citizens' psychological progress. By discussing the mental landscape, one can delve into social dan gender issues within the movies.

The paper will focus on Rindu Kami Pada-Mu (Of Love and Egg, Garin Nugoroho, 2002). By doing textual analysis using theories of Mental Landscape theories and Stuart Hall's Representation, I will have a close reading on the film. I will elaborate on "the other side of Jakarta" and its social issues, namely solidarity and communication Issues. Gender issues, such as the depiction of negative male characters and masculine militarism, will be discussed.

I will begin with the elaboration of Mental Landscape theories.

\section{Jakarta and Mental Landscape}

As discussed earlier, most Indonesian films are set in Jakarta, the capital city of Indonesia. Asrul Sani says that "national" movies are "Jakarta" films, which portray the life, the views, and the aspirations of a specific class of Jakarta residents (Jufri (eds.) 1992: 21). However, he also underlines that most Jakarta 
films are not about the city or its people, but rather about a large town with no name. "Jakarta is merely a set, a place for action because every story needs a setting" (Jufri (eds.) 1992: 23).

Sani writes that he feels the spiritual emptiness of Jakarta represented in films and emphasizes that "...our filmmakers are unable to depict Jakarta as a large city", and most of the movies depicting Jakarta is not accurate (Jufri (eds.) 1992: 21-22). Sani gives examples of how only a few films show the massive difference between two classes of Jakarta people: the world of skyscrapers and luxury housing (the rich people, upper class) and the world of ramshackle huts and fetid rivers (the poor people, lower-class) (Jufri (eds.) 1992: 21-22). As another example, Sani states that the cities in Indonesian films are always pictured in stereotyped images, with a highway full of cars and large and luxurious office buildings (Jufri (eds.) 1992: 24). One aspect of this kind of failure is that the filmmakers are not of an urban mindframe; hence they do not get the spirit and the real condition and situation of urban life (Jufri et at (eds.) 1992: 23).

Sani then highlights the importance of showing not only physical pictures such as prominent buildings and adequate clothing but also a mental landscape. Sani states that the spectators rarely see anything specific or particular indications referring that the city where the films are set in Jakarta. Jakarta is the only physical space that completely voids the symbolic meaning (Jufri (eds.) 1992: 23). Sani writes that instead of the outer images or the physical aspect of life in the city, Jakarta's mental landscape should be shown on screen. "For them, life is a physical expression. In fact, life is something more. There is a world of activity behind the buildings and beneath the skin of urban men" (Jufri (eds.) 1992: 26). Sani mentions some examples on the mental landscape, such as "...the fact that Jakarta is the meeting place for the people from all different sorts of ethnic and cultural backgrounds who are trying to find a social balance and in so doing producing culture and social landscape that differs markedly from the respective regions in which they were raised (Jufri (eds.) 1992: 25).

Notable film critic Andre Bazin mentions that the mental landscape shows the "spiritual vitality" of one city on screen. Bazin uses the concept of the mental landscape when he defends Rossellini's Voyage to Italy. Bazin underlines that the recreated Naples in the film is not false, albeit it is not shot in the real Naples, because it has the quality of wholeness (including the geographical and social setting) and being "filtered" through the consciousness and the attitude of the main characters (Bazin 1972: 98-99). In this context, Bazin also mentions Rossellini as "an artist of rare spiritual vitality." Through the main character's awareness, the spectators can feel the wholeness and spiritual vitality of Naples. Shiel, on a similar topic, mentions the term "mental concept" of the cities, which supposedly signifying human achievement and progress.

This lack of mental landscape happens, as Sani mentions, because the stories are not ones that originate in Jakarta, but only the offshoots of foreign films: a dramatic formula containing the attitudes and elements found in foreign films about large urban areas (Jufri (eds.) 1992: 24).

I argue that by exploring the concept of mental landscape, one can delve into the depth of social and cultural issues of a city's citizens. In this paper, I will apply the theories into Rindu Kami Pada-Mu. To get the big picture, below, I will discuss the story of the film.

\section{Case Study: Rindu Kami Pada-Mu}

There is a good synopsis in Asiatic Film Mediale:

Set in a small Jakarta market hemmed by skyscrapers, the film explores the lives and problems of three children. At the center of the story is the local mosque whose teacher, Bagja, is always looking for advice. Rindu, whose older brother works in constructing the mosque's cupola, has been forcedly separated from him. Though she likes drawing, she refuses to draw cupolas until she is reunited with her brother. Asih is Rindu's best friend. Her mother left her father. Whenever she prays at the mosque, she unrolls her mother's prayer rug beside her because she is sure that her mother will come back home one day. Bimo is an orphan who lives with his older brother, an egg seller at the market, and feels a great affection towards Cantik, a woman he considers a surrogate mother. One by one, each of them come to find the love they seek ${ }^{1}$.

${ }^{1}$ Asiatic Film Mediale.

https://web.archive.org/web/20080221013911/http://www.asiaticafilmmediale.it/2005/uk/schedeautori/GarinNugroho1.html. $10^{\text {th }}$ November 2020 
I compliment the synopsis: Rindu is helped by Imah, the owner of a small shop in the market who lives by herself because her husband left her; Romlah (Asih's mother) left the family Sabeni (Asih's father) often beat her. And although the main stories are about Rindu, Asih, and Bimo, the film also reveals the stories of people surrounding them, for example, Bagja the teacher, Budi the market's owner, Sabeni (Asih's father) the gilder, Seno (Bimo's big brother) the egg seller, Cantik the sales promotion girl and so forth.

\section{Jakarta as Mental Landscape}

From the very beginning, Rindu (played by a real deaf-mute little girl), as narrator, tells the audience that the film is about Jakarta.

Rindu: My friends, I would like to tell you stories about the place I live in. It's a small market in the middle of Jakarta. I want to tell you about my best friends' prayer rug and chicken eggs.

Although shot in a studio, the film represents the mental landscape of Jakarta. I agree with Bazin's view on Roberto Rossellini's Voyage to Italy. He writes that the mental landscape shows the "spiritual vitality" of one city on screen. Bazin underlines that recreated Naples in Rossellini's film is not false, albeit it is not shot in the real Naples, because it has the quality of wholeness (including the geographical and social setting), and being "filtered" through the consciousness and the attitude of the main characters (Bazin 1972: 98-99). Film critic Tony Rayns writes a short description of the mental landscape in Rindu Kami.

Shot entirely in the studio (he built a full-scale street-market and adjoining mosque as his set, with painted backdrops to evoke the nearby countryside), it lovingly recreates (my emphasis, EI) the tone, style and pastel hues of an Indonesian comedy from the heyday of the studio system ${ }^{2}$.

Rayns does not elaborate on this issue further; hence it is my job to do so. Even though the film was not set in the real market, Nugroho and his crews tried to recreate the spiritual vitality of the market (and its people's activities) in a big studio. For example, Rindu Kami has some minor details. The news on television concerning the demolition (the New Order government called it "relocation") of houses, the Bali bombing and political meetings, dangdut ${ }^{3}$ Music on the radio, daily activities in the small market such as people throwing garbage or carrying sacks of rice, a trader is selling his goods claiming "This is Reform price, no gasoline price rising effect," people playing badminton and carambola, ojek motor (motorcycle taxi) and a barber cutting his costumer's hair. All these details strengthen the mental landscape of a slum traditional market in Jakarta. Nugroho even used amateur actors as extras to do their real daily professions on screen, for example, the butchers, the gilders and the coconut cleavers.

Rindu Kami was shot in a studio, but Nugroho and his art division undertook in-depth research to recreate a slum traditional market full of minor details. The production crew's creative team even made a sort of video on the traditional market and its characters, including the how-to and practical things, such as gilding gold, husking coconuts or butchering meat.

Another aspect of these minor details is the various accents and dialects confirming the dwellers' ethnic groups in an urban people society. For example, Bagja (the teacher) is Sundanese (Western Java), and Imah (owner of one of the small shops) comes from Padang (Western Sumatera). This phenomenon emphasizes Jakarta's situation as a melting pot and the center of urban society whose members come from various cities all over Indonesia. And from the first time, Nugroho tends to recreate a mental landscape of a small slum market in the middle of skyscrapers in Jakarta, not only through the setting but also through the acting and actors. In "Behind the Scene of the Film" (Indonesia: Garin Nugroho, 2004), Nugroho stated that all of the actings in this movie tried to describe daily activities. He underlines the importance of mental landscape on screen:

If you observe the movie's acting, it has some realness concept from everyday activities in daily life, which has the verbal or non-verbal context to its architectural or ecosystem dimension of the market itself (Indonesia: Garin Nugroho, 2004).

\footnotetext{
${ }^{2}$ Mercury Cinema. http://mercurycinema.org.au/screenings/love_ans_eggs.html. 4th July 2008. Unfortunately, the link is no longer available.

${ }^{3}$ Dangdut is considered lower-class music.
} 
Nugroho realizes that he shot the film in a studio; thus, he and his crews have to convince the spectators that it represents the market. As he puts it:

The essential studio concept is a visual space in the frame. So, it is not a physical set that we've prepared or built in the location, but how to create structures with the market's images and imaginations (Indonesia: Garin Nugroho, 2004).

As I would argue, the term visual space is compatible with the mental landscape. The creative team even undertook in-depth research on a market to reanimate the spiritual vitality or mental landscape. Arturo $\mathrm{GP}$, the assistant director, says:

All the actors of this movie try to adapt to the market area. Because not all of us have time to visit the real market and learn how to adjust to the actual situation. Finally, we decided to make a video about the market and all the characters in it that we want to put in the movie. For example, we captured every detail in a short documentary. Then we give it to all of the actors to learn (Indonesia: Garin Nugroho, 2004).

The use of amateur people as extras to do their real-life jobs is one of Nugroho's attempts to get the audience closer to the representation of realities. Garin explains another concept concerning these amateur actors:

The other concept is how to manage an ensemble performance of the main actors and actresses and the extras. In this movie, the extras play as an ensemble of daily life in real-life (Indonesia: Garin Nugroho, 2004).

The attempt to manage an ensemble of main actors and extras playing minor jobs as minor details applied in the film reinforces the idea of reanimating the mental landscape of the market.

It is interesting that mostly Nugroho used a static camera to shoot the scenes on the cinematography element. For example, there is a scene where the people, including Budi's family, were hanging out in a place, discussing the current situation in the market. While they discuss, the audience can see Bagja and Sabeni playing badminton. The camera is static and not moving anywhere. So, at first, the audience sees Sabeni swings his racket while Bagja is out of frame. Later, we can see Bagja, who enters the frame to get the shuttlecock and joins the conversation with Imah and Budi. The director of photography, Joseph Fofid, mentions that when he asked Nugroho about the camera style, Nugroho answered that Fofid should watch new Iranian cinema (which was praised by many film critics and film scholars as to the movement to represent the style of Italian neorealism in the 1990s and 2000s) as references (Indonesia: Garin Nugroho, 2004).

\section{Jakarta and Social Issues}

How does Rindu Kami represent post-Reform Jakarta and its social issues? The film tells multi-stories of ordinary people. There are stories of Asih, Rindu, Bimo, Imah, Bagja, Sabeni, Budi, etc. They are members of a poor urban community in post-Reform Jakarta. Thus, there are some social issues represented in the film. As Bagja, the teacher, tells Sabeni in a small chat in the mosque while waiting for prayer time:

Bagja: This area is for poor people ... we can barely find ceramic tiles (for the mosque). Everything is made of raw wood. Even if you use the train for poor people, most of its windows are broken. And if we go to the cinema, we can only go with a foul odor.

I divide the section into urban issues and social issues. The former includes spatial issues and house demolitions or relocations. The latter contains communication problems and the need for solidarity.

\section{Urban Issues}

Rindu Kami represents a slum kampung. In this film, the traditional market itself is the kampung. According to Krausse, kampung (urban village) is a residential area in the urban environment where inhabitants with low socio-economic status and substandard housing constitute a clear majority 
(Krausse 1975: 1). In this film, the market is the core and the heart of the kampung. The dwellers live in the market; their shops and stalls are their houses. They interact in the market. The children study in the small mosque within the market. In short, all of the activities are carried out in the market.

In Rindu Kami, the traditional market is indeed the place for urban people. As I pointed out earlier, people come from a variety of ethnic groups. The image comes from Padang (which is the hometown of Eliana and Bunda), Bagja is Sundanese, Sabeni is Betawi (a Jakarta native), and Budi, the owner of the market, is Chinese. This phenomenon confirms the market as a melting pot society as an urban place. For example, the character Cantik (literal meaning: "beautiful"). She is one of the examples of how urban people try to survive. Cantik comes from her village to Jakarta to find a decent job. She even dates her boss to keep the job. Perhaps she is the prototype of a social climber. A scene where she receives a phone call from her mother asks why Cantik seldom calls home. Cantik answers that she is busy walking around the city as a novice in sales promotion, and she does not come home until in the evening. Her statement that she will not come home to celebrate Idul Fitri (the most celebrated Islamic feast in Muslim culture after the holy fasting month ) is the most important thing. Generally, urban people go back to their hometown to gather with their parents and relatives). Instead, Cantik will send some money from her first salary to her mother. Cantik practices the art of survival in Jakarta, the biggest and the capital city of Indonesia. She treats Jakarta as a money machine, and, like other urban people, she will send her salary back home. The money is more important than the presence of Cantik among the family in her village.

Urban people, as Krausse stated, always face spatial problems. And at the center of the representation of one city in neorealist cinema is the housing crisis (Shiel 2006: 76). While in Eliana, Eliana, the characters deal with the inability to pay house rent. In this film, they face the possibility of house demolitions because most of them live in undocumented houses or on illegal land with no certificates. Rindu is the representation of this case. One night, Rindu and her friends are watching television in Imah's shop. The scenes show city news about demolition.

Television: Entering the second week of this month, the Municipal Government of Jakarta organized the relocation of more than 390 people in the Bantayan Kali district...

Watching the news, the deaf-mute little girl starts to scream and protest, "I don't want my house tore down. I don't want everybody to go!" Imah, her surrogate mother, calms her down and says, "That's not your house anymore, Rindu. Now, this is your home with me." The other children and Budi just stare at them, wondering. Later, the children go home, and Budi continues to watch the news. The TV journalist continues to report the house demolition topic.

Television: ... and this relocation was also followed by a physical clash between the people and the authority. The next relocation occurred at Kampung Batu, Cengkareng, West Jakarta. People who live in Perumnas (Perumahan Nasional, National Housing Enterprise) were forced to leave that area. Fortyfour people from the inhabitants and authorities were injured as caused by fights and stones thrown at each other. Simultaneously, the authorities also destroyed a building at Kampung Karang Anyar, about 200 meters from Kampung Batu. And until this Wednesday, the government has already relocated some people's houses to other villages. According to their plan...

After watching the news, Budi seems to understand Rindu's reaction and turns off the television. In the next scene, Rindu tries to communicate with her friends about what was going on with her and why she acted that way.

Rindu: Six months ago, my brother went out to another town to deliver a dome that he had made. I was looking after our house when suddenly I heard people screaming, "Fire! Demolition!" Then the people got into a fight. I was so afraid. I tried to protect my house. Houses around me were torn down. Suddenly a woman picked me up and carried me away. I tried to speak, but they didn't understand. Land certificates are essential in housing affairs, and unfortunately, most urban people stay in undocumented houses. They are satisfied with having the place to stay, and it is complicated and expensive to have legal certificates. In a scene, there is a discussion between Bagja and Sabeni. Bagja tells about his own family. His siblings always quarrel because they belong to different and even opposite political parties. They have their big Islamic dormitory, but Bagja withdraws from them and prefers to stay in the slum market. He underlines that the land on which the mosque was built was undocumented, 
but his brother sold the land to Budi's father behind his back. Sabine comments, "Weirdly, this important and decent soil has no legal certificate."

Population density reflects housing conditions and the degree of crowding and kampung dwellers' distribution throughout the city (Krausse 1975: 15). The first scenes show the mass density and crowded urban people, thus confirm the theory. But, in the last scenes, most urban people go back to their hometown to celebrate Idul Fitri while the rest stay and feel lonely. People like Bagja, Budi, Imah and Seno do not have reason to go back home. Bagja wants to be lonely and detached from his siblings' dirty political attitude - he'd rather play badminton, karambol or chess, and teaches poor children. Imah, Seno and Bimo do not have any other family. And for Sabeni, Asih and Budi, the market is their home.

\section{Social Issues}

One of the film's first scenes shows an interesting chat about daily life between Sabeni and Bagja in the mosque. "Life out there means standing in line," Bagja discusses poor people like them metaphorically. Sabine answers, "That's right, especially for the poor. Always get stuck in line and crowd for nothing. That's what makes us mad." From the very beginning, this scene hints at the audience that one of the essential issues represented in the movie is about poor people and their problems.

For example, the art of survival in Jakarta is not merely a matter of urban people's attempt to earn money. Imah tells Sabine that her siblings went to Malaysia and Arab to become TKW (Tenaga Kerja Wanita, women work force) to earn a bigger salary. On the other hand, Sabeni was once wealthy, living in a big beautiful building just across the market, but then went bankrupt and moved to the market since he lost in gambling.

I will divide this section into two: the need for solidarity among urban people and communication problems.

\section{Solidarity}

People in the market represented on screen are urban people with a warm atmosphere and close relationship. They mingle with and help each other. Many scenes are depicting the solidarity among them. For example, when a girl tries to commit suicide, people gather and try to help. When Bimo is upset and sulks at everybody, locks the door and leaves his big brother outside, the neighbors try to help. The spectators are shown warm discussions among them. For example, there is a scene where people mingle and relax, discussing life and Budi's family, while Bagja and Sabeni play badminton. Or the children watch television together in Imah's house. Imah helps Rindu and takes Rindu to her home, and saves her from becoming a street child after her house was demolished. The neighbors give their house keys (and their neighbor's phone numbers in the village) and other belonging (such as chicken) to Bagja and Imah before leaving their hometown. And when the copula arrives, people get busy and help each other set it up on the top of the mosque and perform a decent celebration. They support each other-for example, Seno, the egg seller, gives his eggs to be cooked and served for free for this occasion.

One of the Indonesian terms for solidarity is gotong royong (mutual assistance). This is one of the noble values of Indonesian people from a long time ago, and the film criticizes that this great value begins to disappear. One of the first scenes shows a discussion about it. Rindu says, "Lots of people spend their money on shopping but not for charity." The next scene showing the discussion between Bagja and Sabeni depicts these critical voices of the film.

Bagja: If they can afford to have gilding work done at your place, they certainly can donate to the mosque, can't they?

Sabine: You can't compare donation to the mosque to glittering work. If no one asks me for work, how am I going to eat? I just don't understand. It's taking far too long to build a mosque of this size. But everybody wants to wear gold, even if it is fake or just platted. They want to look great on Idul Fitri days, with gold bracelets and necklaces.

In this movie, it tends to underline the vanishing solidarity among the people. They prefer to keep the money for their physical images rather than do charity or other social piety activities. 


\section{Communication Issues}

The film begins with the introduction by the narrator, a deaf-mute girl named Rindu. And Rindu as the narrator reappears in the middle of the film.

Rindu: My market is full of stories. Just like soap operas on TV. Lots of things happen here. Some funny, some strange, some sad. But sometimes kids aren't allowed to watch because there are stories about adult people who get angry.

As a deaf-mute little girl, her impediment makes her speak with unclear pronunciation. Also, in the first scenes, Sabeni, the mosque keeper, is busy doing something with the microphone. And later, Sabeni is represented as a microphone-addict for he uses it very often, from performing azan (prayer call), helping people save the girl who wants to commit suicide, helping to put the copula on top of the mosque, and even just telling Bagja to stop the drawing class to perform the afternoon prayer. I decode those scenes as the way the film criticizes communication problems among the characters. A deaf-mute girl as narrator and a microphone addict represent this issue. Let me elaborate on those scenes:

In frustration, a young woman calls out to her father, who stands no more than twenty feet away from her in a crowded mosque 4 ."I just want my father to speak! Tell him to think what his daughter wants!" the girl cries. But her father does not speak. He just does not know the words. Sabine hands the anguished father a microphone, whispering: "Use this. She'll hear you when you use this." But it does not help since the father is still speechless. Imah approaches him and says, "Please, say something, for God's sake! Look, I have a daughter, she's deaf and mute, but we can communicate with each other." Budi, the young man who owns the market, takes action. He goes up and meets the girl. While playing karambol, a traditional game, Budi talks to her. The girl tells Budi that she used to play karambol with her father when she was a little girl. But, "When we grew bigger, everything has gone!" says the girl. Realizing that her father still does not say anything, the girl begins to protest.

Girl: Why don't you say something, Father? You can't talk to your daughter anymore, can you? Why are you so quiet? Why don't you talk to me?

Father: I don't know what to say ...

Girl: I don't care, just talk.

Father: I don't know what to say.

Girl: Why is it so hard for you to talk to your daughter?

Later on, using the mosque microphone in his hand, the father says something which everybody in the market can hear. "I love you, Fara." Fara, the girl, seems surprised by the sentence her father said. Then, she comments:

Girl: How long has it been since the last time you said that? Never said something like that. I know since I've grown up that I have so many problems. But all I need is to hear those words to help me get through my problems.

This scene depicts that it is hard to communicate between generations, just to say that they love each other. Karambol game and the mosque microphone become the savior.

Communication problems also occur in the relationship between Seno and Bimo and between Seno and Cantik. Seno wants to show that he cares for his little brother through violence and rude words. But to express his love for Cantik, Seno cannot say anything. Later, he just sends Cantik a bunch of eggs with a love symbol on each egg.

In another case, Bagja cannot communicate with his siblings and prefers to dedicate himself to a teacher in a slum market. Budi has lost contact with his siblings, who get busy earning money somewhere else, and prefers to take care of the market. Sabine cannot communicate with his daughter, who misses her mother so much. Ramallah, the mother, left Sabeni because he did not listen to her pleading to stop beating her and always wash his hands with ablution water. The image cannot understand her adopted daughter's action.

4. The sentences are developed from a synopsis (and originally written in): The Global Film Initiative. http://www.globalfilm.org/lens07/love and_eggs.htm. 5th November 2020 


\section{Gender Issues}

To be sure, there are some gender issues in Rindu Kami. Sabine did domestic violence toward his wife, Romlah, thus made her run away. Asih, their daughter, always waits for her mother to come back and in the mosque always unrolls a prayer rug for her mother, and she forbids anybody to fill the space because she believes that her mother will come and sit there. Bimo misses his mother's tenderness since his big brother treats him violently and finds Cantik as his surrogate mother. Imah's husbands left her irresponsibly, and she adopts Rindu and acts as a mother to her-since she has no children and lives alone. Interestingly, Imah's husbands never appear on the screen, whereas Asih's mother only presents in the closing scene, and still, the spectators cannot see her face. Those situations are similar to that of Heni's boyfriend in Eliana, Eliana. Their faces never emerge on screen at all. I think those scenes tell the audience that such issues became hidden, latent and unsolved in the New Order period, but both films reveal and criticize those problems.

I will divide the gender issues into two sections: depicting negative male characters and mothers' roles.

\section{Depiction of Negative Male Characters}

Sabine was a bad husband. He admits it. Once, he was a rich man living in a big building across the market. But he loved to gamble, and it made him lost everything. He also used to hit his wife, and that was the reason why she left the family. Now Sabeni dedicates himself as a mosque keeper in hopes that his wife will come back. As he confesses to Bagja:

Sabine: I used to hit my wife even though I always listened to the sermon every Friday's prayer here. But I never really listened to it. It only passed through my two ears. Never learned it earnestly. I don't know what to do. I am really confused. Maybe if I give my hands here (the mosque-EI), I won't beat my wife anymore.

Once, his wife told him to wash his hands with ablution water five times a day (before the five obligatory prayers) as an attempt to stop raising his hands against her. Now he carries out the advice every day. He tries to be a good husband. Sabine always laments:

Sabine: No matter what happens, I won't sell this necklace and bracelet. They are for you, Ramallah. Didn't you say that if I keep washing my hands with ablution water, I will stop raising my hands against you? Now I always wash my hands when I pray five times a day. But why didn't you come back home? Sabine was once still under the spell of the New Order's Bapakisme (Fathers) and State Ibuism. Soeharto's New Order applied a patriarchal system with the ideology of "azas kekeluargaan" (family principle) and the Family Welfare Movement program (Oey-Gardiner \& Bianpoen 2000: 58). Thus, the father or husband is the central figure in the house and functions as the ruler and the house leader. And one of the functions of a wife is "ikut suami" (following the husband). In Sabeni's case, Sabine was a bad and irresponsible father and husband. Although he was rich, he always gambled, and he hit Romlah because she warned him and gave him advice. Ramallah did not want to follow Sabeni because he led her to the false path. That is the reason she advises him to pray and wash his hands with ablution water. Knowing that Sabeni did not listen to her advice and kept on hitting her, she left. At this point, Romlah is struggling against the New Order patriarchal system embodied in Sabeni.

Another case of an irresponsible husband is Imah's husband. In one scene, Imah tells Sabeni about her past.

Image: My first husband, he said he looked for fortune. He went to Malaysia, Singapore. But never came home to me. The other one, my second husband, he took everything I had. Everything. Including my shop capital. He said he wanted to work abroad. But he never came back home. He just went without a word. This is my life, my destiny.

Sabine: Then we are in the same boat. Your husband left you; my wife left me.

Just like Eliana's father, Imah's husbands are an irresponsible husband and easily leave the family for no particular reasons but their pride, and do so in the name of preserving Fathers. Once again, the patriarchal political system allows a man to do irresponsible actions. In my opinion, both cases are Nugroho's statements as the director to fight against Fathers and State Ibuism. The film criticizes domestic violence and male characters' negative attitude and confirms that the New Order's ideology toward gender roles is getting weak after the Reform.

On the other hand, I argue that the film criticizes female characters and marriage on-screen in the Soeharto era. Before the Reform era, women were represented as silent, passive, powerless or negative. On-screen, women were most commonly seen in domestic settings, dependent on and defined by the 
male protagonist (Sen 2008). And marriage is seen in terms of the man being in control, and the women yielding to his control (Jufri (eds.) 1992: 34). In Rindu Kami, the female characters, especially Imah and Romlah, are no longer framed as passive and powerless persons. They fight in their way. Imah continues to run her business as an independent and strong woman (and even adopts Rindu), and Romlah refused to be under his husband's control and ran away.

\section{Mother and Masculine Militarism}

At the end of the film, the audience can see a tagline on the screen: "For My Mother, Every Mother." Hence, mothers play a pivotal role in the film. Asih and Bimo miss their mother. Rindu is saved by a woman who later plays the role of her mother. Cantik becomes Bimo's target in his search for a mother figure, and he always calls her Ibu (Mother). Asih misses her mother and keeps the prayer rug empty to be filled by her mother.

The relationship between Seno and Bimo, the orphan brothers, can be an example of a motherless family. Seno always acts cruelly and rudely toward his little brother. And he ever mentions their mother's hope and wish. "If Mother saw you like this, she'd be upset. Just look at that!" or "If Mom saw you like this, she'd be mad. She built this place with hard work. Don't you get it?". Seno uses the language of violence and, at the same time, claims that what he is doing is their mother's will. He does not want to know about Bimo's intentions, wants or needs. He always forces Bimo to do whatever he wants in the name of their mother and their goods. This is typically what the New Order did with its people: a militaristic way to force the people.

The New Order regime applied a masculine militarism political system to its people. Political scientist Jun Honna writes that since the birth of the New Order in 1966, military ideology has celebrated the pursuit of economic development as a means to save the nation from the politico-economic catastrophe that took place under President Sukarno (Anderson (ed.) 2001: 55). And the keyword to discuss this issue is Dwifungsi ABRI (the dual function of Indonesian's armed force).

Dwifungsi (double function) was the central doctrine of the military during Soeharto's New Order regime. Dwifungsi insists that, apart from its normal defense function, the military has a socio-political mission to promote national development and ensure political stability. This concept animated the military's systematic and pervasive political intervention and the formation of its political program, organizational ideology, security policies and patterns of civil-military interaction during the Soeharto era (Honna 2003: 3).

Indeed, dwifungsi is a euphemism for military surveillance and national life control (Honna 2003: 3). With its stability and security approach, the military used political repression and ideological surveillance as the primary tools in constructing and maintaining the New Order Regime (Honna 2003: 9, 88). But, since Soeharto's fall, the military's political power and dwifungsi have weakened (Honna 2003: 196).

The image of the New Order regime as a repressive government applying a masculine military system has been discussed by some social, cultural and political scientists. Cultural studies scholar Melani Budianta underlines that the New Order uses a security approach to enhance repressive measures and emphasize unity over cultural diversity. She writes:

What comes out of this concept of security is militarism and security vigilance over civilians that repress freedom of thought and expression. This centralistic system gives little space for pluralism and democratic experience of solving conflicts and differences. When the totalitarian regime had the upper hand, this system was enforced to maintain an illusion of security. However, during the crisis, when economic collapse led to the political faith crisis towards the ruling power, the false security crumbled. Violent ethnic, religious and regional conflicts of a scale unprecedented in national history erupted and spread from Aceh (North Sumatra), various places in Java, Kalimantan, Maluku, to Irian and East Timor (Budianta 2002: 361).

Concerning representations on screen, film scholar Intan Paramaditha points out that nationalism in Indonesian cinema during the New Order was defined within the framework of masculine militarism (Paramaditha 2007: 42). And the New Order's masculine ideal of Fathers requires self-discipline to be a role model in the workplace and the family (Paramaditha 2007: 45). Paramaditha also concludes that masculinity is parallel to national pride and strength. Other exciting scenes in Rindu Kami are the depiction of house demolition undertaken by Jakarta's municipal government and the news footage of 
Bali bombing events on television. Those are the representations of a repressive masculine militaristic political system around urban people applied by both the government and terrorists. Those footages confirm that negative "manly virtues surround Jakarta."

Feminist Saraswati Sunindyo argues that Soeharto's New Order is marked by military rule and capitalist development, "...characterized by both economic progress and military repression where any opposition and criticism toward the regime is easily stigmatized as anti-national and therefore anti-progress." (Sunindyo 1998: 2). Sunindyo's theory can be applied to Seno's case. Seno wants his younger brother to be independent and to develop the egg shop founded by their mother. His crude actions confirm the "military rule," and his purpose demonstrates the "capitalist development." In a way, Sabeni also acts the same. He acted as the military by hitting his wife, and he gambled for the sake of the family's capitalist development, to be richer and prosper. I argue that both Seno and Sabeni are representations of the New Order's masculine militarism.

Allow me to elaborate on one particular scene. One day, Bimo is upset and sulks. He just found out that Cantik (in front of her male boss, also her lover) did not want to be called "Mother." So, Bimo cries, "What's wrong with becoming a mother?" Then, he just closes and locks the door. Nobody can enter the door. Seno and the neighbors try to persuade Bimo to no avail. Bagja, the teacher, asks Seno not to be rude to his little brother. "Don't be rude to little kids. If we are tender, they will be tender, too." But Seno does not listen to him. Once again, Seno tries to force Bimo to open the door in the name of their mother. But now, Bimo answers: "Mom never got angry with me! So what if I cry? When Mom was alive, she let me cry. And then she'd hug me!" In this context, Bimo is raising protests against the values of militaristic masculinity embodied in Seno. Bimo rejects the patriarchal masculine militarism system applied by his big brother. He needs a touch of tenderness, a feminine approach, or I can say: a mother. That is the reason why Bimo always comes to (or should I say: annoys) Cantik and still hangs out in her house - and that makes her boss angry and later fires her.

For thirty-two years, the New Order ruled Indonesia, and the ideology of repressive patriarchal masculine militarism was embodied within many people, unconsciously. Many people adopted the virtues of this ideology. Paramitha writes:

The nation imagined in the New Order cinema reflects what Cynthia Enloe calls "masculinized memory, masculinized hole" (1989: 44). As the real actors who defend the nation's freedom, honor, and women, men require some "manly virtues" summarized by Mosse as courage, competitiveness, stoicism, persistence, sexual virility and restraint (1996: 79). Some of these virtues resonate in the dominant Indonesian models of manliness (Paramaditha 2007: 44-45).

For Seno, hard work, competitiveness, the courage to face every problem, and less playing games are the virtues. And Seno knows that when he mentions their mother as a reason, it might help to make Bimo do what he told him to do. But he says "Mother" without applying the virtues of a mother: feminine, caring, kind and tender. And Bimo spells out his mind by rejecting the concept of masculine militaristic brotherhood. Bimo fights against the ideology of the repressive New Order.

There is one interesting satirical scene on this issue. One day, Bimo and his little friends are playing in front of Seno's egg shop. Seno stops them and asks Bimo, "What are you doing?" They say that they are playing military marches, pretending to be Japanese colonial soldiers. Seno begins to scold Bimo because he always plays around and avoids working, then Seno hits his brother's hat. In my view, this scene criticizes the New Order's masculine militaristic political system satirically. Seno stops the military march game and starts to act as an army officer against his enemy or lower staff and tries to (so to speak) stabilize the situation using a (so-called) security approach. His purpose is to stabilize the problem by working back at the shop and to secure his family's economy and manly virtues.

Allow me to elaborate on the case of Asih, the one who longs for her mother badly. She keeps her mother's prayer rug and takes it with her everywhere. Sabine understands that, so he sells the carpet. But Asih steals the rug from the man who bought it when he is in the barbershop. She even skips school to find the carpet. She waits for the rug to dry after she washed it. She seldom goes home, and if she does, it is only to sleep and eat, realizing that her mother is not there. One day, Asih steals the rug after it was sold to a young man from used rug stalls. After settling the affair with the young man, Sabeni, her father, scolds her, "You act like your mother. You go off and not coming back. You are so annoying!" Asih just stares at his father angrily and later goes into the house. Sabine just does not know how to control Asia. One day, Sabeni buys two plates of food. And, pretending that his wife was beside him, he speaks, 
"Please come home, Ramallah. Where are you? I don't know what to do with Asia. Eat something. I bought you lontong from Siti's place. Go on, eat." Again, a man, or in a broader sense, a state, needs a model of a mother, of femininity. Asih wants her mother; thus, she refuses to come home early. She needs a "home."

Here, I argue that the mother is a concept of tenderness and care and home for the family. Thus, at this point, Rindu Kami criticizes the family-state idea or azas kekeluargaan (the family principle) embodied in Fathers and State Ibuism. In the New Order's State Ibuism, bapak (father) is the primary source of power, and $i b u$ (mother) is one of the mediums of this power (Suryakusuma 2004: 169). But here, a mother is not the medium of patriarchal militarism political system. On the contrary, she stands against it.

There is a scene showing Bagja finds a little bird on the mosque ceiling regarding the mother as a home. He makes a new nest for it, and he invites the children to learn about life through the little bird. "Who knows how to make this little bird grow bigger?" Rindu answers, “...if we provide it with a good home." Through the characters of Bimo, Asih and Rindu (who spoke out against the demolishing process when she saw the news on television) deliver the concept of a tender, caring mother and mother as a home, and at the same time criticizes masculine militarism.

Why does the New Order represented in Seno and Sabeni's cases exclude the role of mothers? Sunindyo illuminates that a female, even one as monumental and sacred as Ibu Pertiwi (Motherland), is constructed here as a fragile, feminine being that needs to be rescued, protected and guarded against the cruelty of a foreign power that has forcefully taken all her wealth away from her (Sunindyo 1998, 4). She writes:

Furthermore, in Indonesian nationalism, Ibu Pertiwi is the manifestation of the feminine, whose interests, needs and happiness must be interpreted and articulated by the masculine counterpart, the Indonesian military institution (Sunindyo 1998: 4-5).

In conclusion, Rindu Kami also represents the remaining State Ibuism and Fathers in society, and at the same time, the attempt to fight against those systems. The ideologies sharpened by the masculine militaristic political system are embodied in Seno and Sabeni, while Bimo and Romlah reject it.

\section{References}

[1] Bazin, Andre. What is Cinema Vol II. Berkeley, Los Angeles, London: University of California Press, 1972.

[2] Budianta, Melani. "Indonesian women's responses to violence: towards an alternative concepts of human security" in Inter-Asia Cultural Studies, Volume 1, Number 2, 2002.

[3] Hall, Stuart (ed). Representation, Cultural Representations and Signifying Practices. London, Thousand Oaks, New Delhi: SAGE Publications, 2003

[4] Honna, Jun. Military Politics and Democratization in Indonesia. London: RoutledgeCurzon, 2003.

[5] Jufri, Moch et al (ed). Indonesian Film Panorama. Jakarta: Permanent Committee of the Indonesian Film Festival, 1992.

[6] Krausse, Gerald Hans. The Kampungs of Jakarta, Indonesia: A Study of Spatial Patterns in Urban Poverty. Michigan, University of Pittsburg: 1975.

[7] Nugroho, Garin \& ISlah Gusmian. Rindu Kami Pada-Mu. Jakarta: Penerbit Nastiti, 2004.

[8] Oey-Gardiner, Mayling and Carla Bianpoen (eds). Indonesian Women, The Journey Continues. Canberra: Research School of Pacific and Asian Studies Publishing The Australian National University: 2000.

[9] Overbey, David (ed). Springtime in Italy: A Reader on Neo-Realism. London: Talisman Books, 1978.

[10] Paramaditha, Intan. "Contesting Indonesian Nationalism and Masculinity in Cinema" in Asian Cinema Vol. 18, No. 2, Fall/Winter 2007.

[11] Pilcher, Jane and Imelda Whelehan. 50 Key concepts in gender studies. London etc: Sage Publications, 2004.

[12] Ruberto, Laura and Kristi Wilson. Italian Neorealism and Global Cinema. Detroit: Wayne State University Press, 2007.

[13] Rusdi, Prima and Riri Riza. Eliana, Eliana, Sebuah Skenario (Eliana, Eliana, a Screenplay). Jakarta: Meta for, 2002. 
[14] Said, Salim. Shadows on the silver screen : a social history of Indonesian film. Jakarta : Lontar Foundation, 1991.

[15] Krishna Sen. "Hidden from history : aspects of Indonesian cinema 1955-65" in Review of Indonesian and Malaysian Affairs, ISSN 0815-7251 vol. 19 (1985), issue 2, page 1-55.

[16] Shiel. Mark. Italian Neorealism, Rebuilding the Cinematic City. London \& New York: Wallflower, 2006.

[17] Sumarno, Marselli and Nan Triveni Achnas. "Indonesia : in two worlds" in The cinemas of Asia Being and Becoming. New Delhi : Macmillan, 2002, p. 152-170

[18] Sunindyo, Saraswati. "When the Earth is Female and the Nation is Mother: Gender, the Armed Forces and Nationalism in Indonesia" in Feminist Review no. 58, Spring 1998, PP. 1-21.

[19] Suryakusuma, Julia. Sex, Power, and Nation (an anthology of writings, 1979-2003). Jakarta: Meta for Publishing, 2004. 